\title{
Use of vitamin D supplements during infancy in an international feeding trial
}

Eveliina Lehtonen ${ }^{1}$, Anne Ormisson ${ }^{2}$, Anita Nucci ${ }^{3}$, David Cuthbertson ${ }^{4}$, Susa Sorkio', Mila Hyytinen ${ }^{5}$, Kirsi Alahuhta ${ }^{1}$, Carol Berseth ${ }^{6}$, Marja Salonen ${ }^{5}$, Shayne Taback7, Margaret Franciscus ${ }^{8}$, Teba González-Frutos ${ }^{9}$, Tuuli E Korhonen ${ }^{1}$, Margaret L Lawson ${ }^{10}$, Dorothy J Becker ${ }^{8}$, Jeffrey P Krischer ${ }^{4}$, Mikael Knip ${ }^{11,12,13}$, Suvi M Virtanen ${ }^{1,14,15, *}$ and TRIGR Investigatorst

${ }^{1}$ Nutrition Unit, National Institute for Health and Welfare, Mannerheimintie 164a, FIN00300, Helsinki, Finland:

${ }^{2}$ Department of Paediatrics, University of Tartu, Tartu, Estonia: ${ }^{3}$ Division of Nutrition, School of Health

Professions, College of Health and Human Sciences, Georgia State University, Atlanta, GA, USA: ${ }^{4}$ Pediatrics

Epidemiology Center, University of South Florida, Tampa, FL, USA: ${ }^{5}$ Institute of Clinical Medicine, University of

Helsinki, Helsinki, Finland: ${ }^{6}$ Medical Affairs Department, Mead Johnson Nutrition, Evansville, IN, USA:

${ }^{7}$ Departments of Pediatrics and Child Health and Community Health Sciences, University of Manitoba,

Winnipeg, Manitoba, Canada: ${ }^{8}$ Children's Hospital of Pittsburgh of UPMC, University of Pittsburgh, Department of Endocrinology, Pittsburgh, PA, USA: ${ }^{9}$ Endocrinology, Diabetes and Nutrition Research Group/CIBERDEM, Hospital Universitario de Cruces, Barakaldo, Bizkaia, Spain: ${ }^{10}$ Division of Endocrinology and Metabolism, Children's Hospital of Eastern Ontario, University of Ottawa, Ottawa, Ontario, Canada: "1 Children's Hospital, University of Helsinki and Helsinki University Central Hospital, Helsinki, Finland: ${ }^{12}$ Folkhälsan Research Center, Helsinki, Finland: ${ }^{13}$ Department of Pediatrics, Tampere University Hospital, Tampere, Finland: ${ }^{14}$ School of Health Sciences, University of Tampere, Tampere, Finland: ${ }^{15}$ Research Center for Child Health, Tampere University and University Hospital, Tampere, Finland

Submitted 31 May 2012: Final revision received 4 January 2013: Accepted 26 February 2013: First published online 24 June 2013

\begin{abstract}
Objective: To examine the use of vitamin D supplements during infancy among the participants in an international infant feeding trial.

Design: Longitudinal study.

Setting: Information about vitamin D supplementation was collected through a validated FFQ at the age of 2 weeks and monthly between the ages of 1 month and 6 months.

Subjects: Infants ( $n$ 2159) with a biological family member affected by type 1 diabetes and with increased human leucocyte antigen-conferred susceptibility to type 1 diabetes from twelve European countries, the USA, Canada and Australia. Results: Daily use of vitamin D supplements was common during the first 6 months of life in Northern and Central Europe ( $>80 \%$ of the infants), with somewhat lower rates observed in Southern Europe (>60\%). In Canada, vitamin D supplementation was more common among exclusively breast-fed than other infants (e.g. $71 \% v .44 \%$ at 6 months of age). Less than $2 \%$ of infants in the USA and Australia received any vitamin D supplementation. Higher gestational age, older maternal age and longer maternal education were study-wide associated with greater use of vitamin D supplements.

Conclusions: Most of the infants received vitamin D supplements during the first 6 months of life in the European countries, whereas in Canada only half and in the USA and Australia very few were given supplementation.
\end{abstract}

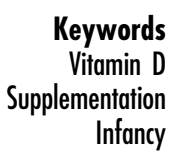

Some developed countries ${ }^{(1-4)}$ have reported a resurgence of vitamin D deficiency and rickets in children and infants, in spite of national recommendations for vitamin $\mathrm{D}$ supplementation in infancy. The content of vitamin D in breast milk is very low ${ }^{(5,6)}$ and thus exclusively breast-fed

$\uparrow$ See Appendix for a full list of the TRIGR Investigators.

children have greater risk of developing vitamin D deficiency than children receiving infant formula ${ }^{(7)}$. Adequacy of prenatal vitamin $\mathrm{D}$ transfer depends on maternal vitamin $\mathrm{D}$ stores, which have been shown to be inadequate in many countries ${ }^{(8)}$. Natural food sources of vitamin $\mathrm{D}$ are few, the most common being egg yolk and fish ${ }^{(9)}$. Vitamin D fortification of foods has become 
common in various countries. Typical fortified food items are milk, margarine, juices and breakfast cereals ${ }^{(10)}$. Also, infant formulas are fortified with vitamin D. Recommendations given for the use of vitamin $\mathrm{D}$ supplements during infancy are currently quite uniform in different countries ${ }^{(11-13)}$, while compliance with these recommendations varies widely ${ }^{(14-16)}$. There is a lack of internationally comparable data on vitamin $\mathrm{D}$ supplement use.

The Trial to Reduce IDDM in the Genetically at Risk (TRIGR; IDDM = insulin-dependent diabetes mellitus) is an international, randomized, double-blinded study testing the hypothesis whether weaning to an extensively hydrolysed infant formula reduces the risk of developing type 1 diabetes (T1D) in children with increased genetic disease susceptibility ${ }^{(17)}$. The TRIGR prospective nutrition questionnaires provide a unique opportunity to compare information on vitamin D supplement use in different countries. Through that study we aimed to determine how vitamin D supplements were used in infancy in the TRIGR countries and to assess adherence with national recommendations. Further, we assessed how infant feeding, sociodemographic and perinatal factors, region and maternal T1D were related to the use of vitamin D supplements.

\section{Experimental methods}

\section{Study population}

Newborn infants with a biological first-degree relative affected by T1D as defined by the WHO were invited into the study. The families were recruited when the mother was in late pregnancy (gestational age 35 weeks or more) or immediately after the delivery. Human leucocyte antigen (HLA) genotyping was performed from cord blood or from a blood sample obtained before the age of $8 \mathrm{~d}$. Infants with increased HLA-conferred susceptibility to T1D were eligible to participate in the study. Altogether 2159 infants from twelve countries in Europe and from the USA, Canada and Australia, born between May 2002 and February 2007, were included in the TRIGR study. Of these, 1095 were born to women with diabetes and 1064 to unaffected women. The TRIGR countries have been divided into seven regions: Northern Europe (Finland and Sweden, $n$ 521); Central Europe I (Czech Republic, Estonia, Hungary and Poland, $n$ 317; i.e. transition economies); Central Europe II (Germany, Luxembourg, the Netherlands and Switzerland, $n$ 184); Southern Europe (Italy and Spain, $n$ 114); the USA ( $n$ 393); Canada ( $n$ 528); and Australia ( $n$ 102). The study was conducted according to the guidelines laid down in the Declaration of Helsinki. The ethical committee of each site approved the study and signed consent was obtained from the parents or legal guardians of the infant.

Exclusion criteria included multiple gestation, an older sibling already participating in TRIGR, recognizable severe illness, gestational age $<35$ weeks, age of the infant more than $7 \mathrm{~d}$ at randomization, or no HLA sample drawn before the age of $8 \mathrm{~d}$. Breast-feeding was encouraged. Infants were randomized to receive either a regular cow's milk-based infant formula or an extensively hydrolysed infant formula (Nutramigen ${ }^{\circledR}$; Mead Johnson, Evansville, IN, USA) upon weaning from breast milk in the first 6-8 months of life. If mother's own breast milk or banked breast milk was not available before randomization, these infants were given Nutramigen in order to avoid exposure to intact cow's milk proteins. Those infants who had received any infant formula other than Nutramigen prior to randomization were excluded. Finally, families having any other reasons (e.g. religious, cultural, unwillingness) to refuse feeding the infant with cow's milk-based products were excluded. Study formulas were enriched with vitamin $\mathrm{D}$. The study did not interfere with the standard feeding practices of the infants other than the avoidance of non-study formulas and foods containing cow's milk or beef.

\section{Dietary interviews}

Information on infant feeding was acquired from the family through standardized dietary interviews. Data on vitamin D supplement use were collected with a validated $^{(18)}$ FFQ at several time points during the first year of life. The content of vitamin D in the supplements was not inquired and therefore the amount of supplemental vitamin D could not be calculated. In the present study, vitamin D supplementation refers to the use of vitamin $\mathrm{D}$ as supplements and does not include the intake of vitamin D from infant formulas or other foods. Mothers were interviewed by a study nurse or dietitian by telephone when the child was 2 weeks, 1 month, 2 months, 4 months and 5 months old, and at study centre visits at the ages of 3 and 6 months.

Of randomized families, $99 \cdot 6 \%$ (varied between $98 \cdot 3$ and $100 \%$ in the different regions) participated in the first interview (at the age of 2 weeks) and $98.8 \%$ (varied between 98.1 and $100 \%$ in the different regions) of them answered the question concerning vitamin D supplement use. Of randomized families, 98.8\% (varied between 95.6 and $100 \%$ in the different regions) participated in the study visit at the age of 6 months and 95.0\% (varied between 92.4 and $98.3 \%$ in the different regions) of them answered the vitamin D supplement question.

\section{Statistics}

The use of vitamin D supplements was divided into two categories: (i) any use and (ii) daily use. The daily use was defined as 4-7 times/week. The use of vitamin D supplements was recorded at each dietary interview. The associations of sociodemographic and perinatal factors with the use of vitamin D supplements at 6 months of age were analysed using univariate and multivariate logistic regression analyses. The results are shown as 
odds ratios and 95\% confidence intervals. All statistical tests were two-sided, at a significance level of $P<0.05$, and performed using the SAS statistical software package version $9 \cdot 1$.

\section{Results}

Vitamin D supplementation from 2 weeks to 6 months of age varied significantly by region (Table 1 ). Most of the infants who received vitamin D supplements were given them daily. From 2 weeks up to 6 months of age, more than $80 \%$ of the infants received vitamin D supplements in Northern (Finland and Sweden) and Central Europe (Czech Republic, Estonia, Hungary, Poland, Germany, Luxembourg, the Netherlands and Switzerland), over $60 \%$ in Southern Europe (Italy and Spain), and approximately $50 \%$ in Canada. Less than $2 \%$ of infants in the USA and Australia received vitamin D supplements between the age of 2 weeks and 6 months (Table 1).

There were no significant differences in the vitamin D supplementation of infants between mothers with and without T1D (see online supplementary material, Supplemental Table 1). When vitamin D supplement use was examined in relation to exclusive breast-feeding, differences between those exclusively breast-fed up to at least 5 months and the others were notable only for Canada, with exclusively breast-fed infants receiving more supplementation than the other infants (Table 2).

Maternal T1D, caesarean section and living in Central Europe II, Southern Europe and Canada were associated with less frequent use of vitamin D supplements, whereas higher gestational age was associated with more frequent use of vitamin D supplements at the age of 6 months in univariate analysis (Table 3). When all the factors associated with the use of vitamin D supplementation at 6 months of age were considered simultaneously in a multivariate analysis, higher gestational age, older maternal age and longer maternal education were associated with more frequent use of vitamin D supplements (Table 3). Infants living in Central Europe II, Southern Europe and Canada were less likely to get vitamin D supplementation when compared with those living in Northern Europe. The USA and Australia were not included in the analysis as the use of vitamin D supplements in those regions was very low.

\section{Discussion}

In the TRIGR study, the use of vitamin D supplements during the first 6 months of life varied by region with more than $80 \%$ of the infants living in Northern and Central Europe receiving supplementation, over $60 \%$ in Southern Europe and only half in Canada. The use of vitamin D supplements was extremely rare in the USA and Australia, where very few infants received any supplementation during the first 6 months of life. Higher gestational age and maternal age and longer education were associated with more frequent use of vitamin D supplements. Maternal T1D was not associated with vitamin D supplement use. Considerable difference in supplementation by breast-feeding status was only seen

Table 1 Use of vitamin D supplementation in different regions according to child age: TRIGR (Trial to Reduce IDDM in the Genetically at Risk) study, 2002-2007

\begin{tabular}{|c|c|c|c|c|c|c|c|}
\hline Regiont & $\begin{array}{c}0-2 \text { weeks } \\
(\%)\end{array}$ & $\begin{array}{c}2 \text { weeks-1 month } \\
(\%)\end{array}$ & $\begin{array}{c}1-2 \text { months } \\
(\%)\end{array}$ & $\begin{array}{c}2-3 \text { months } \\
(\%)\end{array}$ & $\begin{array}{c}\text { 3-4 months } \\
(\%)\end{array}$ & $\begin{array}{c}4-5 \text { months } \\
(\%)\end{array}$ & $\begin{array}{c}\text { 5-6 months } \\
(\%)\end{array}$ \\
\hline \multicolumn{8}{|c|}{ Northern Europe ( $n$ 521) } \\
\hline Any use & $23 \cdot 6$ & $84 \cdot 3$ & $94 \cdot 2$ & $97 \cdot 3$ & $97 \cdot 7$ & $98 \cdot 1$ & $97 \cdot 3$ \\
\hline Daily use§ & $2 \cdot 8$ & $79 \cdot 7$ & $92 \cdot 4$ & $94 \cdot 7$ & $95 \cdot 0$ & $96 \cdot 0$ & $96 \cdot 0$ \\
\hline \multicolumn{8}{|c|}{ Central Europe I ( $n$ 317) } \\
\hline Any use & $46 \cdot 6$ & $91 \cdot 6$ & $96 \cdot 0$ & $97 \cdot 3$ & $96 \cdot 3$ & $97 \cdot 3$ & $97 \cdot 3$ \\
\hline Daily use & $22 \cdot 7$ & $84 \cdot 4$ & $94 \cdot 7$ & $95 \cdot 7$ & $95 \cdot 7$ & $97 \cdot 0$ & $95 \cdot 6$ \\
\hline \multicolumn{8}{|c|}{ Central Europe II ( $n$ 184) } \\
\hline Any use & $52 \cdot 7$ & $80 \cdot 8$ & $87 \cdot 4$ & $87 \cdot 2$ & $84 \cdot 4$ & $84 \cdot 3$ & $82 \cdot 6$ \\
\hline Daily use & $41 \cdot 3$ & $74 \cdot 7$ & $85 \cdot 2$ & $83 . \overline{9}$ & $80 \cdot 0$ & $82 \cdot 0$ & $79 \cdot 2$ \\
\hline \multicolumn{8}{|c|}{ Southern Europe ( $n$ 114) } \\
\hline Any use & $30 \cdot 9$ & $62 \cdot 3$ & $67 \cdot 9$ & 68.9 & $71 \cdot 8$ & $73 \cdot 5$ & $77 \cdot 5$ \\
\hline Daily use & $23 \cdot 6$ & $60 \cdot 4$ & $67 \cdot 0$ & $67 \cdot 0$ & $70 \cdot 9$ & $72 \cdot 6$ & $75 \cdot 5$ \\
\hline \multicolumn{8}{|l|}{ USA ( $n$ 393) } \\
\hline Any use & $0 \cdot 3$ & $0 \cdot 8$ & $1 \cdot 0$ & $1 \cdot 0$ & $1 \cdot 6$ & $1 \cdot 6$ & $1 \cdot 6$ \\
\hline Daily use & $0 \cdot 3$ & 0.5 & $1 \cdot 0$ & $0 \cdot 8$ & $1 \cdot 0$ & $1 \cdot 0$ & $0 \cdot 8$ \\
\hline \multicolumn{8}{|c|}{ Canada ( $n$ 528) } \\
\hline Any use & $30 \cdot 8$ & $49 \cdot 8$ & $55 \cdot 0$ & $55 \cdot 0$ & $53 \cdot 3$ & $47 \cdot 7$ & $46 \cdot 0$ \\
\hline Daily use & $22 \cdot 1$ & $42 \cdot 6$ & $47 \cdot 5$ & $47 \cdot 6$ & $45 \cdot 3$ & $40 \cdot 5$ & $37 \cdot 3$ \\
\hline \multicolumn{8}{|c|}{ Australia ( $n$ 102) } \\
\hline Any use & $1 \cdot 0$ & 0.0 & 0.0 & $1 \cdot 0$ & 0.0 & $1 \cdot 0$ & $1 \cdot 0$ \\
\hline Daily use & $1 \cdot 0$ & 0.0 & 0.0 & $1 \cdot 0$ & 0.0 & $1 \cdot 0$ & $1 \cdot 0$ \\
\hline
\end{tabular}

IDDM, insulin-dependent diabetes mellitus.

†The following regions were included: Northern Europe (Finland and Sweden); Central Europe I (Czech Republic, Estonia, Hungary and Poland; transition economies); Central Europe II (Germany, Luxembourg, the Netherlands and Switzerland); Southern Europe (Italy and Spain); the USA; Canada; and Australia. $\ddagger$ Use of vitamin D supplements in any frequency.

$\S$ Use of vitamin D supplements 4-7 times/week. 


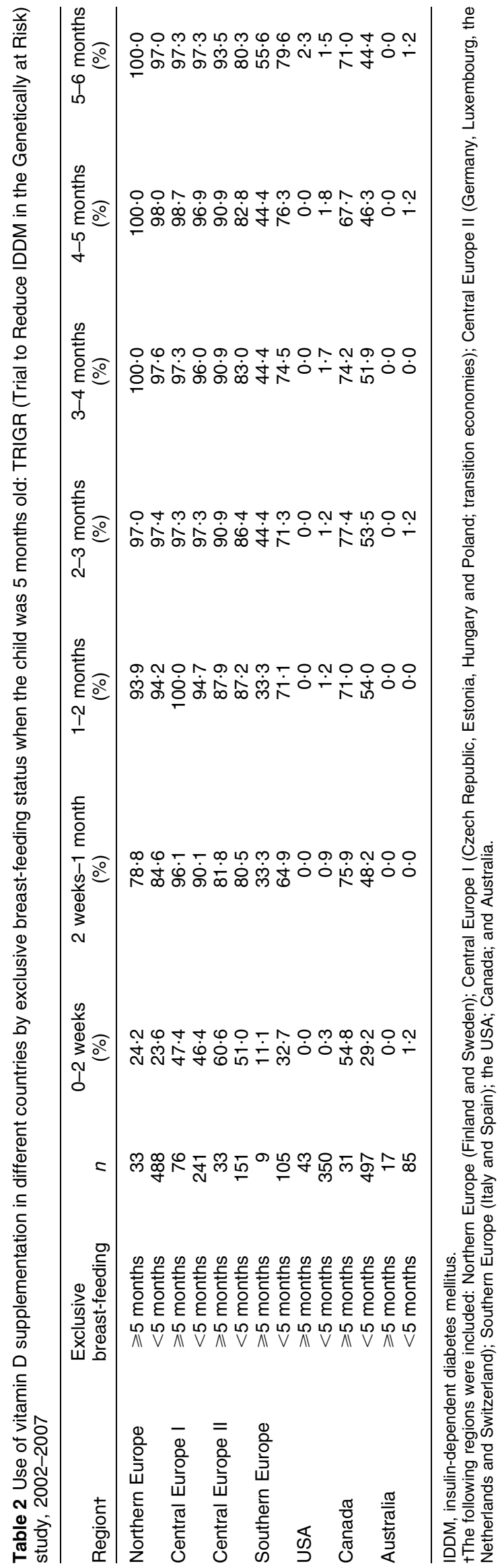

in Canada, where exclusively breast-fed infants received more supplementation.

The present study provides valuable comparative information about vitamin D supplement use in infancy from fifteen countries on three continents. The information on vitamin D supplementation was acquired by an FFQ which was validated against two $48 \mathrm{~h}$ recall interviews ${ }^{(18)}$. In the validation study, the agreement of the two methods for vitamin D supplementation was shown to be moderate.

Limitations of the present study are that we did not assess either the dosage of vitamin D supplementation nor vitamin D intake from food. Nor had we an opportunity to measure vitamin D from the peripheral circulation. We were not able to collect data regarding vitamin $D$ supplement use after the age of 6 months. The generalizability of the findings is limited because the study subjects represent a select group of children as they have an increased HLA-conferred susceptibility to T1D as well as a family member affected by T1D. The use of vitamin D supplements may be more frequent in the present risk group since vitamin $\mathrm{D}$ intake has been associated with decreased risk of $\mathrm{T}_{1} \mathrm{D}^{(19)}$.

At the time of the dietary data collection in the TRIGR study (from 2002 to 2007), several of the countries involved in TRIGR had given dietary recommendations for vitamin D supplementation in infants: Sweden and Switzerland recommended a daily supplementation of $10 \mu \mathrm{g}^{(20,21)}$; Finland and Estonia from 5 to $10 \mu \mathrm{g}$ depending on breast-feeding status or amount of infant formula consumed ${ }^{(22,23)}$; Germany $10 \mu \mathrm{g}^{(24)}$; the Netherlands $5 \mu \mathrm{g}^{(25)}$; and Canada $10 \mu \mathrm{g}$ until the intake from other sources reached that level ${ }^{(13)}$. In the USA, vitamin D supplements were previously recommended only for those breast-fed infants not exposed to adequate sunlight and/or whose mothers were vitamin D-deficient ${ }^{(26)}$. From 2003 onwards, a daily supplementation of $5 \mu \mathrm{g}$ was recommended in the USA unless a certain amount of fortified infant formula or milk was consumed ${ }^{(27)}$, and in 2008, the recommended dosage for supplementation was doubled to $10 \mu \mathrm{g}^{(28)}$. Also Finland ${ }^{(12)}$, Estonia ${ }^{(29)}$ and the Netherlands ${ }^{(25)}$ have increased their recommendation for vitamin D supplementation to $10 \mu \mathrm{g}$, and Poland ${ }^{(30)}$, Italy $^{(31)}$ and Spain ${ }^{(32)}$ have given a recommendation of $10 \mu \mathrm{g}$ daily depending on breast-feeding status or amount of infant formula consumed. In the Czech Republic, the recommended dose for vitamin D supplementation is currently $12.5 \mu \mathrm{g} / \mathrm{d}^{(33)}$ and in Hungary $10 \mu \mathrm{g}^{(34)}$. In Australia, vitamin D supplements are recommended only for specific infant groups with very little sun exposure due to dark skin and/or children with veiled mothers ${ }^{(35)}$. With the exception of Australia, the overall recommended amounts of supplementation are now very similar during the first year of life in these countries and also the differences in the recommended age at introduction and end of supplementation are minor. The European Society for 
Table 3 Risk for the use of vitamin D supplements according to sociodemographic, perinatal and other background factors at 6 months of age: TRIGR (Trial to Reduce IDDM in the Genetically at Risk) study, 2002-2007

\begin{tabular}{|c|c|c|c|c|c|c|}
\hline & OR & $95 \% \mathrm{Cl}$ & $P$ value & Adjustedt OR & $95 \% \mathrm{Cl}$ & $P$ value \\
\hline Age of mother (years) & $1 \cdot 00$ & $0.98,1.03$ & 0.73 & 1.04 & $1 \cdot 00,1 \cdot 08$ & $0.04^{*}$ \\
\hline Maternal education (years) & $1 \cdot 03$ & $0.99,1.07$ & $0 \cdot 17$ & $1 \cdot 07$ & $1 \cdot 00,1 \cdot 14$ & $0 \cdot 04^{\star}$ \\
\hline Paternal education (years) & 1.03 & $0.99,1.07$ & $0 \cdot 17$ & 1.06 & $1 \cdot 00,1 \cdot 12$ & 0.07 \\
\hline Maternal type 1 diabetes, yes $v$. no & $0 \cdot 64$ & $0 \cdot 50,0 \cdot 81$ & $<0.001^{*}$ & $1 \cdot 14$ & $0.78,1.68$ & 0.50 \\
\hline Gestational age (weeks) & $1 \cdot 21$ & $1 \cdot 13,1 \cdot 31$ & $<0.001^{*}$ & $1 \cdot 17$ & $1 \cdot 03,1 \cdot 32$ & $0 \cdot 01^{*}$ \\
\hline Male $v$. female sex of the child & $1 \cdot 05$ & $0 \cdot 82,1 \cdot 33$ & $0 \cdot 71$ & $0 \cdot 88$ & $0.64,1 \cdot 20$ & 0.42 \\
\hline Caesarean section $v$. other mode of birth & $0 \cdot 78$ & $0.61,0.99$ & $0 \cdot 04^{*}$ & 0.84 & $0 \cdot 60,1 \cdot 18$ & $0 \cdot 31$ \\
\hline Ponderal index $\left(\mathrm{kg} / \mathrm{m}^{3}\right)$ & $1 \cdot 01$ & $0 \cdot 84,1 \cdot 22$ & 0.90 & $0 \cdot 91$ & $0 \cdot 72,1 \cdot 17$ & $0 \cdot 47$ \\
\hline \multicolumn{7}{|l|}{ Region $\ddagger$} \\
\hline Northern Europe (reference) & $1 \cdot 00$ & - & - & 1.00 & - & - \\
\hline Central Europe I & 1.01 & $0 \cdot 41,2 \cdot 46$ & 0.99 & $1 \cdot 22$ & $0 \cdot 47,3 \cdot 17$ & 0.68 \\
\hline Central Europe II & $0 \cdot 13$ & $0.07,0.26$ & $<0.001^{*}$ & $0 \cdot 11$ & $0 \cdot 05,0.23$ & $<0.001^{*}$ \\
\hline Southern Europe & $0 \cdot 10$ & $0 \cdot 05,0.20$ & $<0.001^{*}$ & $0 \cdot 11$ & $0.05,0.24$ & $<0.001^{*}$ \\
\hline Canada & $0 \cdot 02$ & $0.01,0.04$ & $<0.001^{*}$ & 0.02 & $0.01,0.04$ & $<0 \cdot 001^{*}$ \\
\hline
\end{tabular}

IDDM, insulin-dependent diabetes mellitus.

${ }^{\star} P<0.05$.

tAdjusted for all the variables in the table.

¥The following regions were included: Northern Europe (Finland and Sweden); Central Europe I (Czech Republic, Estonia, Hungary and Poland; transition economies); Central Europe II (Germany, Luxembourg, the Netherlands and Switzerland); Southern Europe (Italy and Spain); and Canada. The USA and Australia were not included in the analysis as the use of vitamin D supplements in those regions was very low (Tables 1 and 2; online supplementary material, Supplemental Table 1).

Pediatric Endocrinology Bone Club recommends that all breast-fed infants should receive $10 \mu \mathrm{g}$ of supplemental vitamin $\mathrm{D}$ daily from birth until they are receiving the same amount of vitamin D daily from their diet ${ }^{(11)}$.

In the current study, the majority of the European children received vitamin D supplements. Almost all the infants (96\%) in Northern Europe (Finland and Sweden) were provided vitamin D supplementation daily at the age of 6 months. In an earlier Finnish cohort study, the proportion of children receiving vitamin D supplements was slightly lower: $91 \%$ of infants were given supplements at 6 months of age ${ }^{(16)}$. In a large Swedish cohort, $99 \%$ of the infants had received vitamin D supplements during the first year of life ${ }^{(36)}$. In our survey, $96 \%$ of infants were receiving vitamin D supplementation daily at the age of 6 months in Central Europe I countries (transition economies), which include Czech Republic, Estonia, Hungary and Poland. In a previous Polish study, $82 \%$ of infants received regular and 14\% occasional vitamin D supplementation at the age of 6 months ${ }^{(37)}$. In the Central Europe II countries (Germany, Luxembourg, the Netherlands and Switzerland) $79 \%$ of the infants were given vitamin D supplements daily at the age of 6 months and $76 \%$ of infants in Southern Europe (Italy and Spain). In an earlier Swiss study, only $64 \%$ of infants aged 0-9 months had been given vitamin D supplements within the preceding $24 \mathrm{~h}^{(38)}$. In a Canadian survey the supplementation rate was higher in 2010 than in our study: $80 \%$ of infants were supplemented with vitamin D at 2 months of age ${ }^{(39)}$. In the USA, a low use of vitamin D supplements during infancy has also been reported in previous studies, being only $4-16 \%$ during the first 10 months of life in $2005-2008^{(14,15)}$. It is possible that the low rates of supplementation observed in the US TRIGR population are partly due to the fact that the American
Academy of Pediatrics recommendation for vitamin D supplementation was introduced only in 2003, after the TRIGR intervention had started. The lack of vitamin D recommendations for the general population in Australia is reflected in the results of the present study and it is likely that the children participating in TRIGR did not belong to those specific groups for whom supplementation has been recommended.

Even though exclusively breast-fed children have greater risk of developing vitamin $\mathrm{D}$ deficiency than children receiving infant formula ${ }^{(7)}$, it was observed in a recent Canadian report that also those infants consuming both breast milk and infant formula and those consuming only infant formula represented groups at risk of not meeting the recommended $10 \mu \mathrm{g}$ of vitamin D daily ${ }^{(40)}$. In a study from the USA it was observed that most (81-98\% during the first 10 months of life) exclusively formula-fed infants met the 2003 American Academy of Pediatrics recommendation $(5 \mu \mathrm{g}$ vitamin $\mathrm{D} / \mathrm{d})$ that was applicable during the data collection, but only $20-37 \%$ would have met the current recommendation of $10 \mu \mathrm{g} / \mathrm{d}^{(14)}$. Among infants fed both breast milk and infant formula, only around one-third met the target of $5 \mu \mathrm{g} / \mathrm{d}$ and less than $15 \%$ would have met the current recommendation. In most TRIGR regions, there were no significant differences in vitamin D supplementation between infants exclusively breast-fed for at least 5 months and those who were not. Canada was an exception in this respect; supplement use was more common in the exclusively breast-fed group. Higher frequencies of use compared with the present study but similar difference by breast-feeding status was seen in a report from Canada where $98 \%$ of exclusively breast-fed and $88 \%$ of infants consuming both breast milk and infant formula had received vitamin D supplementation at some point during the first 6 months 
of life in $2008^{(40)}$. None of the formula-fed infants had been supplemented with vitamin D. In 2010 in another Canadian study, the supplementation rate of infants receiving only breast milk at 2 months of age was $91 \%$ while the corresponding figures for infants receiving both breast milk and infant formula or only infant formula were $79 \%$ and $20 \%$, respectively ${ }^{(39)}$. Also, in the USA differences in vitamin D supplementation of infants fed only breast milk (5-13\% received supplementation), infants consuming both breast milk and infant formula (4-11\% received supplementation) and infants consuming only infant formula ( $1-4 \%$ received supplementation) during the first 10 months of life were observed over the time period $2005-2007^{(14)}$.

Some sociodemographic factors have been associated with the use of vitamin D supplements. Mothers who are younger have been reported to be less likely to give vitamin D supplements to their infants ${ }^{(16,38)}$; this was also seen in our study. Having more than one child in the family may be associated with less use of vitamin D supplements ${ }^{(16,38)}$. Higher maternal education was associated with more frequent use of vitamin D supplements in the current study as has been reported before ${ }^{(40,41)}$.

Vitamin D is particularly important for the skeleton because it is needed for $\mathrm{Ca}$ absorption from the intestine. Insufficient vitamin D intake causes rickets in children and osteomalacia in adults. Vitamin D supplementation in infancy has also been associated with reduced risk of $\mathrm{T}_{1} \mathrm{D}^{(19)}$. There is also some evidence that vitamin $\mathrm{D}$ deficiency is associated with increased risk of cardiovascular and autoimmune diseases in adults and lower respiratory infections in children ${ }^{(42)}$. The main natural source of vitamin $\mathrm{D}$ is the synthesis in the skin induced by $\mathrm{UV}$ radiation from the $\operatorname{sun}^{(9)}$. With minimal sun exposure, for example at northern latitudes, or due to protective clothing or sunscreen, other sources of vitamin D are required. Because the intake of vitamin $\mathrm{D}$ from food is inadequate for most infants, supplementation is necessary. It is clear that new protocols and strategies are needed in some regions to ensure that families get enough information on the importance of adequate vitamin D intake, especially in infancy and childhood. Re-education about the importance of supplementation is essential as families tend to stop using supplements over time ${ }^{(16)}$.

\section{Conclusion}

The importance of adequate vitamin D intake in infancy is well known and supported by the current recommendations for use of vitamin D supplements. In the present study, the recommendations regarding vitamin D supplementation were quite well followed during the first 6 months of life in European countries and to some extent in Canada. The use of vitamin D supplements was conspicuously low in the USA and Australia. Due to increasing concern regarding the high prevalence of vitamin $\mathrm{D}$ deficiency in childhood, and especially in breast-fed infants, action is needed to train health-care personnel and develop strategies to inform families about the importance of adequate intake of vitamin $\mathrm{D}$ in infancy, particularly in those exclusively breast-fed.

\section{Acknowledgements}

Sources of funding: This work was supported by grant numbers HD040364, HD042444 and HD051997 from the National Institute of Child Health and Human Development and the National Institute of Diabetes and Digestive and Kidney Diseases, National Institutes of Health (the content is solely the responsibility of the authors and does not necessarily represent the official views of the National Institutes of Health); the Canadian Institutes of Health Research; the Juvenile Diabetes Research Foundation International; the Commission of the European Communities specific RTD programme 'Quality of Life and Management of Living Resources', contract number QLK1-2002-00372 'Diabetes Prevention' (the study does not reflect the views of the European Commission and in no way anticipates the Commission's future policy in this area); the Academy of Finland; and the EFSD/JDRF/Novo Nordisk Focused Research Grant. The study formulas were provided free of charge by Mead Johnson Nutrition. Conflicts of interest: None of the authors had a personal or financial conflict of interest. The industry sponsors had no role in the design and conduct of the study; the collection, management, analysis and interpretation of the data; or the preparation, review and approval of the manuscript. Authors' contributions: S.M.V. and D.C. had full access to all data in the study and take responsibility for integrity of the data and the accuracy of the data analysis. Study concept and design: S.M.V., S.S. and M.K. Acquisition of data: A.O., A.N., D.C., M.S., M.F., T.G.-F., D.J.B., J.P.K., M.K. and S.M.V. Analysis and interpretation of data: D.C., S.M.V., E.L., S.S., K.A. and J.P.K. Drafting of the manuscript: E.L., S.S., K.A. and S.M.V. Critical revision of the manuscript for important intellectual content: all of the authors. Statistical analysis: D.C. and J.P.K. Obtained funding: M.K., D.J.B., J.P.K. and S.M.V. Administrative, technical and material support: E.L., S.S., K.A. and M.S. Study supervision: S.M.V., J.P.K. and M.K. Acknowledgements: The authors would like to thank the TRIGR investigators, coordinators, dietitians and study nurses at all clinical sites as well as the Data Management Unit, laboratories and administrative centres for their enthusiasm and excellent work, and also all TRIGR families for their willingness to participate.

\section{Supplementary material}

To view supplementary material for this article, please visit http://dx.doi.org/10.1017/S1368980013001122 


\section{References}

1. Ward LM, Gaboury I, Ladhani M et al. (2007) Vitamin Ddeficiency rickets among children in Canada. CMAJ 177, 161-166.

2. Gordon CM, Feldman HA, Sinclair L et al. (2008) Prevalence of vitamin D deficiency among healthy infants and toddlers. Arch Pediatr Adolesc Med 162, 505-512.

3. Callaghan AL, Moy RJ, Booth IW et al. (2006) Incidence of symptomatic vitamin D deficiency. Arch Dis Child 91, 606-607.

4. Robinson PD, Hogler W, Craig ME et al. (2006) The re-emerging burden of rickets: a decade of experience from Sydney. Arch Dis Child 91, 564-568.

5. Hollis BW, Roos BA, Draper HH et al. (1981) Vitamin D and its metabolites in human and bovine milk. J Nutr 111, $1240-1248$

6. Kunz C, Niesen M, von Lilienfeld-Toal H et al. (1984) Vitamin D, 25-hydroxy-vitamin D and 1,25-dihydroxyvitamin D in cow's milk, infant formulas and breast milk during different stages of lactation. Int J Vitam Nutr Res $\mathbf{5 4}$, 141-148.

7. Kreiter SR, Schwartz RP, Kirkman Jr HN et al. (2000) Nutritional rickets in African American breast-fed infants. J Pediatr 137, 153-157.

8. Weiler H, Fitzpatrick-Wong S, Veitch R et al. (2005) Vitamin D deficiency and whole-body and femur bone mass relative to weight in healthy newborns. CMAJ 172, $757-761$.

9. Cavalier E, Delanaye P, Chapelle JP et al. (2009) Vitamin D: current status and perspectives. Clin Chem Lab Med $\mathbf{4 7}$, 120-127.

10. Calvo MS, Whiting SJ \& Barton CN (2004) Vitamin D fortification in the United States and Canada: current status and data needs. Am J Clin Nutr 80, 1710-1716.

11. Hochberg Z, Bereket A, Davenport M et al. (2002) Consensus development for the supplementation of vitamin D in childhood and adolescence. Horm Res $\mathbf{5 8}$, 39-51.

12. Terveyden ja hyvinvoinnin laitos (National Institute for Health and Welfare), Valtion ravitsemusneuvottelukunta (National Nutrition Council) \& Suomen lääkäriyhdistys (Finnish Medical Association) (2011) Lasten, nuorten ja raskaana olevien sekä imettävien äitien D-vitamiinivalmisteiden käyttö varmistettava (Recommendations for the use of vitamin D supplements during childhood, adolescence, pregnancy and lactation). http://www.ravitsemusneuvottelukunta.fi/portal/fi/ tiedotteet_ja_kannanotot/(accessed January 2011).

13. Health Canada (2004) Vitamin D supplementation for breastfed infants: 2004 Health Canada recommendation. http://www.hc-sc.gc.ca/fn-an/nutrition/infant-nourisson/ vita_d_supp-eng.php (accessed January 2011).

14. Perrine CG, Sharma AJ, Jefferds ME et al. (2010) Adherence to vitamin D recommendations among US infants. Pediatrics 125, 627-632.

15. Taylor JA, Geyer LJ \& Feldman KW (2010) Use of supplemental vitamin D among infants breastfed for prolonged periods. Pediatrics 125, 105-111.

16. Räsänen M, Kronberg-Kippilä C, Ahonen S et al. (2006) Intake of vitamin D by Finnish children aged 3 months to 3 years in relation to sociodemographic factors. Eur J Clin Nutr 60, 1317-1322.

17. The TRIGR Study Group (2007) Study design of the Trial to Reduce IDDM in the Genetically at Risk (TRIGR). Pediatr Diabetes 8, 117-137.

18. Vahatalo L, Barlund S, Hannila ML et al. (2006) Relative validity of a dietary interview for assessing infant diet and compliance in a dietary intervention trial. Matern Child Nutr 2, 181-187.
19. Hypponen E, Laara E, Reunanen A et al. (2001) Intake of vitamin $\mathrm{D}$ and risk of type 1 diabetes: a birth-cohort study. Lancet 358, 1500-1503.

20. Livsmedelsverket (National Food Administration) (2005) De Svenska Näringsrekommendationerna 2005 (Swedish Nutrition Recommendations 2005). http://www.slv.se/sv/ grupp1/Mat-och-naring/Svenska-narings-rekommendationer/ (accessed June 2010).

21. Spalinger J, Schubiger G \& Baerlocher K (2003) Ernährung gesunder Neugeborener in den ersten Lebenstagen (Diet of healthy newborns during the first days of life). http:// www.neonet.ch/assets/pdf/Ernaehrung_d.pdf (accessed February 2011).

22. Hasunen K, Kalavainen M, Keinonen H et al. (2004) Lapsi, perhe ja ruoka. Imeväis- ja leikki-ikäisten, odottavien ja imettävien äitien ravitsemussuositus. Sosiaali- ja terveysministeriön julkaisuja 2004:11 (The Child, Family and Food. Nutrition Recommendations for Infants and Young Children As Well As Pregnant and Breastfeeding Mothers. Publications of the Ministry of Social Affairs and Health 2004:11). Helsinki: Sosiaali- ja terveysministeriö (Ministry of Social Affairs and Health).

23. Mägi M-L (2005) Rahhiit (rickets). In Väikelapse tervisebäired ja kuidas nendega toime tulla (Health Problems of Toddlers and How to Manage Them), pp. 10-11 [A Ormisson and H Varendi, editors]. Tartu: OÜ Dada AD.

24. Deutsche Gesellschaft für Sozialpädiatrie (German Association of Social Paediatrics) (1982) Rachitisprophylaxe (Prevention of rickets). http://www.fke-do.de/content.php? seite $=$ seiten $/$ inhalt.php\&details $=504$ (accessed February 2011).

25. Health Council of the Netherlands (2008) Towards an Adequate Intake of Vitamin D. Publication no. 2008/15E. The Hague: Health Council of the Netherlands.

26. American Academy of Pediatrics, Work Group on Breastfeeding (1997) Breastfeeding and the use of human milk. Pediatrics 100, 1035-1039.

27. Gartner LM \& Greer FR (2003) Prevention of rickets and vitamin D deficiency: new guidelines for vitamin $\mathrm{D}$ intake. Pediatrics 111, 908-910.

28. Wagner CL \& Greer FR (2008) Prevention of rickets and vitamin D deficiency in infants, children, and adolescents. Pediatrics 122, 1142-1152.

29. Estonian Association of Family Doctors (2010) Kuni 18aastaste laste tervisekontrolli juhend (Guidelines for health control of children under 18 years). http://www.haigekassa. ee/uploads/userfiles/0-18\%20tervisekontroll04012010_16plik.pdf (accessed February 2011).

30. Members of the Recommendation Committee (2010) Prophylaxis of vitamin D deficiency - Polish Recommendations 2009. Endokrynol Pol 61, 228-232.

31. Bartolozzi G (2008) Prevenzione del rachitismo: ancora sulla vitamina D (Prevention of rickets: still on vitamin D). http://www.medicoebambino.com/?id=AP0810_10.html (accessed June 2010).

32. La Asociación Española de Pediatría de Atención Primaria (The Spanish Association of Primary Care Pediatrics) (2009) Vitamina D Profiláctica (Prophylactic vitamin D). http:// aepap.org/previnfad/vitamina_d.htm (accessed June 2010).

33. Frühauf P (2008) Výživa kojence (The infant feeding). Pediatr pro Praxi 9, Suppl. C, 28.

34. Az Egészségügyi Minisztérium (Ministry of Health) (2009) Szakmai protokollja az egészséges csecsemő táplálásáról (Guidelines for nutritional requirements of healthy infants). Egészségügyi Közlöny (Hung) 21, 3043-3064.

35. National Health and Medical Research Council (2006) Nutrient reference values for Australia and New Zealand including recommended dietary intakes. http://www.nhmrc. gov.au/_files_nhmrc/file/publications/synopses/n35.pdf (accessed January 2010). 
36. Brekke HK \& Ludvigsson J (2007) Vitamin D supplementation and diabetes-related autoimmunity in the ABIS study. Pediatr Diabetes 8, 11-14.

37. Pludowski P, Socha P, Karczmarewicz E et al. (2011) Vitamin D supplementation and status in infants: a prospective cohort observational study. J Pediatr Gastroenterol Nutr 53, 93-99.

38. Dratva J, Merten S \& Ackermann-Liebrich U (2006) Vitamin D supplementation in Swiss infants. Swiss Med Wkly 136, 473-481.

39. Crocker B, Green TJ, Barr SI et al. (2011) Very high vitamin $\mathrm{D}$ supplementation rates among infants aged 2 months in
Vancouver and Richmond, British Columbia, Canada. BMC Public Health 11, 905.

40. Gallo S, Jean-Philippe S, Rodd C et al. (2010) Vitamin D supplementation of Canadian infants: practices of Montreal mothers. Appl Physiol Nutr Metab 35, 303-309.

41. Marjamäki L, Räsänen M, Uusitalo L et al. (2004) Use of vitamin $\mathrm{D}$ and other dietary supplements by Finnish children at the age of 2 and 3 years. Int J Vitam Nutr Res 74, 27-34

42. Dawodu A \& Wagner CL (2012) Prevention of vitamin D deficiency in mothers and infants worldwide - a paradigm shift. Paediatr Int Child Health 32, 3-13. 
List of TRIGR investigators for publications/version January 2013

\begin{tabular}{|c|c|c|c|c|}
\hline Administration/Country & Study centre & Last name & First name & Position \\
\hline Data Safety Monitoring Board & & $\begin{array}{l}\text { Mandrup-Poulsen } \\
\text { Arjas } \\
\text { Lernmark } \\
\text { Schmidt } \\
\text { Krischer }\end{array}$ & $\begin{array}{l}\text { Thomas } \\
\text { Elias } \\
\text { Alke } \\
\text { Barbara } \\
\text { Jeffrey P. }\end{array}$ & $\begin{array}{l}\text { Chair } \\
\text { Member } \\
\text { Member } \\
\text { Member } \\
\text { Observer }\end{array}$ \\
\hline $\begin{array}{l}\text { International Coordinating } \\
\text { Center (ICC), Helsinki, } \\
\text { Finland }\end{array}$ & & $\begin{array}{l}\text { Åkerblom } \\
\text { Hyytinen } \\
\text { Knip } \\
\text { Koski } \\
\text { Koski } \\
\text { Pajakkala } \\
\text { Salonen }\end{array}$ & $\begin{array}{l}\text { Hans K. } \\
\text { Mila } \\
\text { Mikael } \\
\text { Katriina } \\
\text { Matti } \\
\text { Eeva } \\
\text { Marja }\end{array}$ & $\begin{array}{l}\text { PI of the Study until } 30.6 .08 \text {, Deputy PI from } \\
1.7 .2008 \\
\text { European Study Monitor } \\
\text { Deputy PI until } 30.6 .2008, \text { PI of the Study } \\
\text { from 1.7.2008, National Investigator } \\
\text { European Study Monitor } \\
\text { IT Specialist } \\
\text { European Study Monitor } \\
\text { Study Coordinator }\end{array}$ \\
\hline $\begin{array}{l}\text { Data Management Unit (DMU), } \\
\text { Tampa, FL, USA }\end{array}$ & & $\begin{array}{l}\text { Cuthbertson } \\
\text { Krischer } \\
\text { Shanker }\end{array}$ & $\begin{array}{l}\text { David } \\
\text { Jeffrey P. } \\
\text { Linda }\end{array}$ & $\begin{array}{l}\text { Biostatistician } \\
\text { PI of the DMU } \\
\text { Coordinator }\end{array}$ \\
\hline $\begin{array}{l}\text { Canadian Coordinating Center, } \\
\text { London and Ottawa, ON }\end{array}$ & & $\begin{array}{l}\text { Bradley } \\
\text { Dosch } \\
\text { Dupré } \\
\text { Fraser } \\
\text { Lawson } \\
\text { Mahon } \\
\text { Sermer } \\
\text { Taback }\end{array}$ & $\begin{array}{l}\begin{array}{l}\text { Brenda } \\
\text { Hans-Michael } \\
\text { John }\end{array} \\
\text { William } \\
\text { Margaret } \\
\text { Jeffrey L. } \\
\text { Mathew } \\
\text { Shayne P. }\end{array}$ & $\begin{array}{l}\text { National Coordinator } \\
\text { Co-Investigator for Canada } \\
\text { Co-PI for North America, National } \\
\text { Investigator, Executive Committee } \\
\text { Co-Investigator for Canada } \\
\text { Executive Committee } \\
\text { Co-Investigator for Canada } \\
\text { Executive Committee } \\
\text { Co-Investigator for Canada } \\
\text { Executive Committee } \\
\text { Co-Investigator for Canada } \\
\text { Executive Committee } \\
\text { Co-Investigator for Canada, } \\
\text { Executive Committee }\end{array}$ \\
\hline $\begin{array}{l}\text { USA Coordinating Center, } \\
\text { Pittsburgh, PA and Seattle, } \\
\text { WA }\end{array}$ & & $\begin{array}{l}\text { Becker } \\
\text { Franciscus } \\
\text { Nucci } \\
\text { Palmer }\end{array}$ & $\begin{array}{l}\text { Dorothy } \\
\text { Margaret } \\
\text { Anita } \\
\text { Jerry }\end{array}$ & $\begin{array}{l}\text { Co-PI for North America, } \\
\text { National Investigator, Executive Committee } \\
\text { National Coordinator } \\
\text { Nutrition Coordinator of North America } \\
\text { Executive Committee }\end{array}$ \\
\hline $\begin{array}{l}\text { Nutritional Epidemiology Unit, } \\
\text { Helsinki, Finland }\end{array}$ & & $\begin{array}{l}\text { Pekkala } \\
\text { Virtanen }\end{array}$ & $\begin{array}{l}\text { Minna } \\
\text { Suvi M. }\end{array}$ & $\begin{array}{l}\text { Research Fellow } \\
\text { Head of Nutritional Epidemiology Unit }\end{array}$ \\
\hline Australia & $\begin{array}{l}\text { AUS01 - Westmead - Children's Hospital } \\
\text { AUS02 - Newcastle - John Hunter Children's Hospital } \\
\text { AUS03 - Sydney - Sydney Children's Hospital }\end{array}$ & $\begin{array}{l}\text { Catteau } \\
\text { Howard } \\
\text { Crock } \\
\text { Craig }\end{array}$ & $\begin{array}{l}\text { Jacki } \\
\text { Neville } \\
\text { Patricia } \\
\text { Maria }\end{array}$ & $\begin{array}{l}\text { National Coordinator } \\
\text { National Investigator } \\
\text { Local Investigator } \\
\text { Local Investigator }\end{array}$ \\
\hline
\end{tabular}


Appendix Continued

Study centre

CAN01 - London - St. Joseph's Health Care Centre

CANO2 - Vancouver - Children's and Women's Health Centre of British Columbia

CAN03 - Calgary - Alberta Children's Hospital

CANO4 - Edmonton - Walter MacKenzie Health Sciences

CAN05 - Winnipeg - Health Sciences Centre

CANO6 - Ottawa - Children's Hospital of Eastern

Ontario and The Ottawa Hospital

CANO7 - Toronto Mount Sinai Hospital/Hospital for Sick Children

CAN08 - Quebec - CHUQ

CAN09 - Saint John - Regional Hospital

CAN10 - Montreal - L' Hôpital Sainte-Justine

CAN11 - Montreal Children's Hospital

CAN12 - Halifax - IWK Health Centre/Dalhousie

CAN13 - St. John's - Janeway Child Health Center

CAN14 - Kingston - Kingston General Hospital/

Queen's University

CAN15 - Regina - Regina Qu'Appelle

CAN16 - Saskatoon - Royal University Hospital

CAN17 - Peterborough - Peterborough Regional

Health Centre

CAN18 - Victoria - Vancouver Island Health Research Centre

CZE01 - Prague - Faculty Hospital Kralovske Vinohrady

Last name

Clarson

Bere

Thompson

Metzger

Kwan

Stephure

Schwarz

Girgis

Thompson

Taback

Catte

Lawson

Bradley

Daneman

Sermer

Martin

Morin

Frenette

Ferland

Sanderson

Heath

Huot

Gonthier

Thibeault

Legault

Luforte

Scott

Bridger

Bridger

Crummel

Houlden

Breen

Kelly

Kelly
Sankaran

Penner

White

King

Popkin

Robson

Al Taji

Aldhoon

Mendlova

Vavrinec

Vosahlo

First name

Position

Local Investigator

Co-ordinator

Cheril L

David

Daniel

Colleen

Jennifer

Daniele

Wendy

Wendy

Marilyn

Shayne P.

Daniel

Margaret L.

Brenda

Denis

Mary-Jean

Mary-Jean

Lyne

Suzanne

Susan

Kathy

Céline

Monique

Maryse

Diane

Elizabeth A.

Karen

Tracey

Chery

Adriana

George

Koravangattu

Marie

Richard A.

Nancy

James

Laurie

Eva

Irena

Pavla

Jan
Co-ordinator (In Transition)

Local Investigator

Co-Investigato

Co-ordinator

Local Investigator

Co-ordinator

Local Investigator

Local Investigator

Co-ordinator

Local Investigator

Co-Investigator

Co-ordinator

Local Investigator

Local Investigator

Co-ordinator

Local Investigator

Co-ordinator

Local Investigator

Co-Investigator

Co-ordinator

Local Investigator

Co-ordinator

Local Investigator

Co-ordinator

Local Investigator

Co-ordinator

Local Investigator

Co-ordinator

Local Investigator

Co-ordinator

Local Investigator

Co-ordinator

Local Investigator

Co-ordinator

Local Investigator

Co-ordinator

National Coordinator

Co-Investigator

National Coordinator

National Investigator

Co-Investigator 
Appendix Continued

\begin{tabular}{|c|c|c|c|c|}
\hline Administration/Country & Study centre & Last name & First name & Position \\
\hline & $\begin{array}{l}\text { CZE02 - Brno - Hospital Milosrdnych Bratri } \\
\text { CZE03 - Olomouc - Faculty Hospital Olomouc } \\
\text { CZE04 - Usti nad Labem - Hospital of Masryk } \\
\text { CZE05 - Ceske Budejovice - Hospital Ceske } \\
\text { Budejovice } \\
\text { CZE06 - Plzen - Faculty Hospital PIzen } \\
\text { CZE07 - Zlin - Hospital of Bata }\end{array}$ & $\begin{array}{l}\text { Brazdova } \\
\text { Venhacova } \\
\text { Venhacova } \\
\text { Cipra } \\
\text { Tomsikova } \\
\text { Krckova } \\
\text { Gogelova }\end{array}$ & $\begin{array}{l}\text { Ludmila } \\
\text { Jitrenka } \\
\text { Petra } \\
\text { Adam } \\
\text { Zdenka } \\
\text { Petra } \\
\text { Pavla }\end{array}$ & $\begin{array}{l}\text { Local Investigator } \\
\text { Local Investigator } \\
\text { Co-Investigator } \\
\text { Local Investigator } \\
\text { Local Investigator } \\
\text { Local Investigator } \\
\text { Local Investigator }\end{array}$ \\
\hline Estonia & $\begin{array}{l}\text { EST01 - Tallinn - Tallinn Children's Hospital } \\
\text { EST02 - Tartu - Tartu University Children's Hospital }\end{array}$ & $\begin{array}{l}\text { Einberg } \\
\text { Riikjärv } \\
\text { Ormisson } \\
\text { Tillmann }\end{array}$ & $\begin{array}{l}\text { Ülle } \\
\text { Mall-Anne } \\
\text { Anne } \\
\text { Vallo }\end{array}$ & $\begin{array}{l}\text { Co-Investigator } \\
\text { Local Investigator } \\
\text { National Investigator } \\
\text { Co-Investigator }\end{array}$ \\
\hline Finland & $\begin{array}{l}\text { FIN01 - Helsinki - Hospital for Children and } \\
\text { Adolescents, University of Helsinki } \\
\text { FIN02 - Helsinki - Department of Obstetrics and } \\
\text { Gynecology, University of Helsinki } \\
\text { FIN03 - Espoo - Jorvi Hospital } \\
\text { FIN04 - Kotka - Kymenlaakso Central Hospital } \\
\text { FIN05 - Lahti - Paijat-Hame Central Hospital } \\
\text { FIN06 - Tampere - Department of Pediatrics, Tampere } \\
\text { University Hospital } \\
\text { FIN07 - Pori - Satakunta Central Hospital } \\
\text { FIN08 - Jyväskylä - Central Finland Central Hospital } \\
\text { FIN09 - Seinäjoki - South Ostrobotnia Central Hospital } \\
\text { FIN10 - Hyvinkää - Hyvinkää Hospital } \\
\text { FIN11 - Kuopio - Department of Pediatrics, Kuopio } \\
\text { University Hospital } \\
\text { FIN12 - Oulu - Department of Pediatrics, Oulu } \\
\text { University Hospital } \\
\text { FIN13 - Hämeenlinna - Kanta-Hame Central Hospital } \\
\text { FIN14 - Vaasa - Vaasa Central Hospital } \\
\text { FIN15 - Lappeenranta - South Carelian Central } \\
\text { Hospital } \\
\text { FIN16 - Mikkeli - Mikkeli Central Hospital }\end{array}$ & $\begin{array}{l}\text { Kleemola } \\
\text { Parkkola } \\
\text { Suomalainen } \\
\text { Järvenpää } \\
\text { Hämälainen } \\
\text { Haavisto } \\
\text { Tenhola } \\
\text { Lautala } \\
\text { Salonen } \\
\text { Aspholm } \\
\text { Siljander } \\
\text { Holm } \\
\text { Ylitalo } \\
\text { Lounamaa } \\
\text { Nuuja } \\
\text { Talvitie } \\
\text { Lindström } \\
\text { Huopio } \\
\text { Pesola } \\
\text { Veijola } \\
\text { Tapanainen } \\
\text { Alar } \\
\text { Korpela } \\
\text { Käär } \\
\text { Mustila } \\
\text { Virransalo } \\
\text { Nykänen }\end{array}$ & $\begin{array}{l}\text { Päivi } \\
\text { Anna } \\
\text { Heli } \\
\text { Anna-Liisa } \\
\text { Anu-Maaria } \\
\text { Hannu } \\
\text { Sirpa } \\
\text { Pentti } \\
\text { Pia } \\
\text { Susanna } \\
\text { Heli } \\
\text { Carita } \\
\text { Samuli } \\
\text { Raisa } \\
\text { Anja } \\
\text { Timo } \\
\text { Kaija } \\
\text { Hanna } \\
\text { Jouni } \\
\text { Riitta } \\
\text { Päivi } \\
\text { Abram } \\
\text { Paavo } \\
\text { Marja-Liisa } \\
\text { Taina } \\
\text { Ritva } \\
\text { Päivi }\end{array}$ & $\begin{array}{l}\text { National Coordinator } \\
\text { Local Investigator } \\
\text { National Coordinator } \\
\text { Local Investigator } \\
\text { Local Investigator } \\
\text { Local Investigator } \\
\text { Local Investigator } \\
\text { Local Investigator } \\
\text { Local Investigator } \\
\text { Local Investigator } \\
\text { Co-Investigator } \\
\text { Local Investigator } \\
\text { Co-Investigator } \\
\text { Co-Investigator } \\
\text { Local Investigator } \\
\text { Local Investigator } \\
\text { Local Investigator } \\
\text { Local Investigator } \\
\text { Co-Investigator } \\
\text { Local Investigator } \\
\text { Co-Investigator } \\
\text { Local Investigator } \\
\text { Local Investigator } \\
\text { Local Investigator } \\
\text { Local Investigator } \\
\text { Local Investigator } \\
\text { Local Investigator }\end{array}$ \\
\hline Germany & $\begin{array}{l}\text { GER01 - Hannover - Kinder- und Jugendkrankenhaus - } \\
\text { Auf der Bult }\end{array}$ & $\begin{array}{l}\text { Aschemeier } \\
\text { Danne } \\
\text { Kordonouri }\end{array}$ & $\begin{array}{l}\text { Bärbel } \\
\text { Thomas } \\
\text { Olga }\end{array}$ & $\begin{array}{l}\text { National Coordinator } \\
\text { National Investigator } \\
\text { Co-Investigator }\end{array}$ \\
\hline Hungary & HUN01 - Budapest - Semmelweis Medical University & $\begin{array}{l}\text { Krikovszky } \\
\text { Madácsy }\end{array}$ & $\begin{array}{l}\text { Dóra } \\
\text { László }\end{array}$ & $\begin{array}{l}\text { Co-Investigator } \\
\text { National Investigator }\end{array}$ \\
\hline
\end{tabular}




\begin{tabular}{|c|c|c|c|c|}
\hline Administration/Country & Study centre & Last name & First name & Position \\
\hline Italy & $\begin{array}{l}\text { ITA01 - Rome - University Campus Bio-Medico of } \\
\text { Rome } \\
\text { SAR01 - Cagliari - St. Michele Hospital }\end{array}$ & $\begin{array}{l}\text { Khazrai } \\
\text { Maddaloni } \\
\text { Pozzilli } \\
\text { Mannu } \\
\text { Songini }\end{array}$ & $\begin{array}{l}\text { Yeganeh Manon } \\
\text { Ernesto } \\
\text { Paolo } \\
\text { Carla } \\
\text { Marco }\end{array}$ & $\begin{array}{l}\text { Local Coordinator } \\
\text { Local Coordinator } \\
\text { National Investigator } \\
\text { Local Coordinator } \\
\text { National Investigator }\end{array}$ \\
\hline Luxembourg & $\begin{array}{l}\text { LUX01 - Luxembourg - Centre Hospitalier de } \\
\text { Luxembourg }\end{array}$ & $\begin{array}{l}\text { de Beaufort } \\
\text { Schierloh }\end{array}$ & $\begin{array}{l}\text { Carine } \\
\text { Ulrike }\end{array}$ & $\begin{array}{l}\text { National Investigator } \\
\text { Co-Investigator }\end{array}$ \\
\hline The Netherlands & NET01 - Rotterdam - Sophia Children's Hospital & $\begin{array}{l}\text { Bruining } \\
\text { Bisschoff }\end{array}$ & $\begin{array}{l}\text { Jan } \\
\text { Margriet }\end{array}$ & $\begin{array}{l}\text { National Investigator } \\
\text { National Coordinator }\end{array}$ \\
\hline Poland & $\begin{array}{l}\text { POL01 - Wroclaw - Medical University of Wroclaw } \\
\text { POL02 - Krakow - Polish-American Children's Hospital }\end{array}$ & $\begin{array}{l}\text { Basiak } \\
\text { Wasikowa } \\
\text { Ciechanowska }\end{array}$ & $\begin{array}{l}\text { Aleksander } \\
\text { Renata } \\
\text { Marta }\end{array}$ & $\begin{array}{l}\text { Co-Investigator } \\
\text { National Investigator } \\
\text { Local Investigator }\end{array}$ \\
\hline
\end{tabular}

Spain

Sweden

Switzerland
POL04 - Lodz - Medical University of Lodz

POL05 - Lodz - Polish Mother's Memorial Hospital (I.C.Z.M.P.)

SPA01 - Hospital de Cruces, University of Basque Country, CIBERDEM-CIBERER, Baracaldo, Bizkaia

SPA02 - Madrid - Hospital Clinico San Carlos

SPA03 - Madrid - Hospital Gregorio Marañon

SWE01 - Linköping - University of Linköping

SWE02 - Uddevalla - Uddevalla Hospital

SWE03 - Göteborg - Gothenburg - The Queen Silvia Children's Hospital

SWE05 - Halmstad - Halmstad Hospital

SWE06 - Trollhättan - Trollhättan Hospital

SWE07 - Norrköping - Vrinnevi Hospital

SWE08 - Borås - Borås Hospital

SWE09 - Karskrona - Karlskrona Hospital

SWE10 - Örebro - University Hospital

SWE11 - Jönköping -

SWT01 - Zürich - University Children's Hospital

USA01 - Pittsburgh - Children's Hospital of Pittsburgh

USA02 - Seattle - VA Puget Sound Health Care System and University of Washington USA03 - St. Louis - Washington University
Ciechanowska

Deja

Jarosz-Chobo

Szadkowsk

Cypryk

Zawodniak-

Castano

Gonzalez Frutos

Oyarzabal

Serrano-Ríos

Martínez-Larrad

Hawkins

Rodriguez Arnau

Ludvigsson

Smolinska Konefa

Hanas

Lindblad

Nilsson

Fors

Nordwall

Lindh

Edenwall

Aman

Johansson

Gadient

Schoenle

Becker

Marta

Grazyna

Przemyslawa

Agnieszka

Katarzyna

Malgorzata

Luis

Teba

Mirentxu
Manuel

María Teres

Federico Gustavo

Dolores

Johnny

Malgorzat

Ragnar

Bengt

Nils-Osten

Hans

Maria

Agne

Hans

Jan

Calle

Margrit

Dorothy

Daftary

Franciscus

Gilmour

Palmer

Taculad

Tanner-Blasiar

White

Ashi

Margaret

Carol

Jerry

Rachel

Marilyn

Neil

Local Investigator

Co-Investigator

Local Investigator

Local Investigator

Local Investigato

Co-Investigator

National Investigator

Local Coordinator

Co-Investigator

National Investigator

Local Coordinator

Co-Investigator

Co-Investigator

National Investigator

National Coordinator

Local Investigator

Local Investigator

Local Investigator

Local Investigator

Local Investigator

Local Investigator

Local Investigator

Local Investigator

National Coordinator

National Investigator

USA National Investigator / Pittsburgh Local Investigator 
Appendix Continued

\begin{tabular}{|c|c|c|c|c|}
\hline Administration/Country & Study centre & Last name & First name & Position \\
\hline & $\begin{array}{l}\text { USA04 - Los Angeles - Mattel Children's Hospital of } \\
\text { UCLA } \\
\text { USA05 - Ponce - Ponce School of Medicine } \\
\text { USA06 - New York - Naomie Berrie Diabetes Center }\end{array}$ & $\begin{array}{l}\text { Devaskar } \\
\text { Horowitz } \\
\text { Rogers } \\
\text { Colon } \\
\text { Frazer } \\
\text { Torres } \\
\text { Goland } \\
\text { Greenberg } \\
\text { Nelson } \\
\text { Schachner } \\
\text { Softness }\end{array}$ & $\begin{array}{l}\text { Uday } \\
\text { Heather } \\
\text { Lisa } \\
\text { Roxana } \\
\text { Teresa } \\
\text { Jose } \\
\text { Robin } \\
\text { Ellen } \\
\text { Maudene } \\
\text { Holly } \\
\text { Barney }\end{array}$ & $\begin{array}{l}\text { Local Investigator } \\
\text { Coordinator/Dietitian } \\
\text { Coordinator/Dietitian } \\
\text { Coordinator } \\
\text { Co-Investigator } \\
\text { Local Investigator } \\
\text { Local Investigator } \\
\text { Coordinator } \\
\text { Dietitian } \\
\text { Co-Investigator } \\
\text { Co-Investigator }\end{array}$ \\
\hline Laboratories & $\begin{array}{l}\text { HLA-typing Laboratory - Turku - Finland } \\
\text { HLA-typing Laboratory - Pittsburgh - PA - USA } \\
\text { Cow's Milk Antibody Laboratory - Helsinki - Finland } \\
\text { Autoantibody Laboratory - Helsinki - Finland } \\
\text { T-Cell Laboratory - Helsinki - Finland } \\
\text { T-Cell Laboratory - Toronto - ON - Canada }\end{array}$ & $\begin{array}{l}\text { Ilonen } \\
\text { Trucco } \\
\text { Nichol } \\
\text { Savilahti } \\
\text { Härkönen } \\
\text { Knip } \\
\text { Vaarala } \\
\text { Luopajärvi } \\
\text { Dosch }\end{array}$ & $\begin{array}{l}\text { Jorma } \\
\text { Massimo } \\
\text { Lynn } \\
\text { Erkki } \\
\text { Taina } \\
\text { Mikael } \\
\text { Outi } \\
\text { Kristiina } \\
\text { Hans-Michael }\end{array}$ & $\begin{array}{l}\text { Head of HLA-typing Laboratory } \\
\text { Head of HLA-typing Laboratory } \\
\text { Chief Technician } \\
\text { Head of Cow's Milk Antibody Laboratory } \\
\text { Co-Investigator } \\
\text { Head of Antibody Laboratory } \\
\text { Head of T-Cell Laboratory } \\
\text { Co-Investigator } \\
\text { Head of T-Cell Laboratory }\end{array}$ \\
\hline
\end{tabular}

